\title{
FORMING OF PERSONALITY MEDIACOMPETENCE IN THE CONDITIONS OF DIGITAL TECHNOLOGIES DEVELOPMENT
}

\section{Kostyrko T. N.}

\section{INTRODUCTION}

We live in many spaces at once. The main ones are physical, informational and virtual. Today, while the coronavirus quarantined people, it underestimated the role of the physical space, but overestimated the status of information and virtual. We lack news, so the status of the information space is growing. Having gained a lot of free time, we overestimate the status of virtual space in our lives as a result. Our time has flowed from physical space to informational and virtual. And a person is determined by where it lives, where it spends more of his time. As a result, for many people TV series have become life, and life - TV series. By the way, many streaming services have opened free use of their resources, leading people away from real life. This clearly increases theprobability of that we will react to everything according to the models of the heroes of TV series. Mediacompetence must pay attention to diverting us from virtual role models for life ${ }^{1}$.

The global use of digital media and network applications, as well as rapid technological progres in big data, machine learning, artificial intelligence and other new digital technologies have fundamentally changed the information and communication space around the world. New challenges have risen, such as problems with data ownership and use, trust and privacy, dignity and human autonomy, increasing automation of decision-making processes, accountability and transparency of algorithms, and so on. The situation is also complicated by the fact that worldwide only a dozen technology giants play a dominant role in the regulation and development of technologies.

The technological revolution and the transformation of the media environment are also creating challenges for media information literacy

\footnotetext{
${ }^{1}$ Pocheptsov Georgiy. Koronavirus vskryvaet konflikty: media i feyki, politika i vragi [Coronavirus reveals conflicts: media and fakes, politics and enemies]. Retrieved from: https://www.stopfake.org/ru/koronavirus-vskryvaet-konflikty-media-i-fejki-politika-ivragi/.
} 
(MIL) education, which aims to develop the knowledge, skills, attitudes and competencies needed to access, search, critically evaluate, intelligently use and disseminate content, in order to work successfully and live in the age of digital technology. At the core of the MIL is a holistic approach that includes a rational, emotional, and cultural understanding that reflects the values of different civilizational approaches rather than technical skills. However, in the context of traditional MIL education, the implications of the introduction of new technologies are less discussed, while the potential of MIL is not fully exploited.

The concepts of media education, media literacy and media competence are now important categories for any science. Today, media education disciplines play an important role not only in the training of future professionals in the field of media, but also in the process of carrying out any professional activity. With the help of mass media (media) and the ability to properly use their resources, you can significantly simplify and increase the efficiency of certain aspects of the work of any specialist.

It is time to distinguish the concepts of information literacy and media literacy, information competence and media competence. Information competence and literacy reveal the technical aspect of product creation, these concepts are associated with computer technology, while media literacy and media competence involve the use by the individual of the media product that conveys the means of communication, in particular, using information technology $\mathrm{y}^{2}$.

\section{Media information literacy of the individual - terminological diversity}

In 2019, the term "information literacy" (IL) will be forty-five years old. It was first used by Paul Zurkowski in his report "The Information Services Environment: Relationship and Priorities" for the US National Commission on Libraries and Informatics, where he described the basic skills needed by service workers in the United States at the time ${ }^{3}$. The author of the term considered it a universal phenomenon and explained it by the following

${ }^{2}$ Onkovych Ganna (2013) Mediakompetentnist - fakhova yakist suchasnoho spetsialista [Media competence - the professional quality of a modern specialist]. Mediakompetentnist fakhivtsia: kolektyvna monohrafiia [Media competence of a specialist: a collective monograph]. Kyev: Logos, p. 7.

3 Chemerys I. M. (2008) Formuvannia profesiinoi kompetentnosti maibutnikh zhurnalistiv zasobamy inshomovnykh periodychnykh vydan [Formationof future journalistsprofessional competence by foreign language periodicals' means] ( $\mathrm{PhD}$ in Pedagogic sciences). Kyiv: Institute of Higher Education of the National Academy of Pedagogical Sciences of Ukraine, p. 45. 
three factors: 1) searches for information differ in time and purpose; 2) there are a variety of sources and methods of access, due to which approaches to addressing this issue are constantly and rapidly changing; 3 ) The information we work with reflects a much larger amount of human experience ${ }^{4}$.

Today, the word "literacy" is widely used to denote the availability of skills and basic knowledge in a particular subject area (in collective terms computer literacy, health literacy, civic literacy). When the terms "literacy" and "computer" are combined to form a new concept ("computer literacy"), the meaning is obvious. However, in combination with the word "information", the term "literacy" for different people took on a completely different meaning. Therefore, understanding the concept of "information literacy" for many today is still a problem ${ }^{5}$. Disagreements on this issue stimulated the search for other options. Expert of the European Network of School Libraries and Information Literacy, Professor of the University of Amsterdam Albert Buchhorst in his analytical article "Media and Information Literacy and its "friends" 6 notes that back in 1995, researchers established the existence of nineteen related terms. with information literacy: literacy of the adult population; increased literacy; basic literacy; double literacy; public literacy; computer literacy; critical literacy; cultural literacy; primary literacy; family literacy; functional literacy; informative literacy; marginal literacy; media literacy; minimum literacy; limited literacy; necessary literacy; visual literacy; literacy in the workplace.There are also many other types of literacy in scientific sources, such as: civic literacy; news literacy; information literacy; literacy in matters of health information; transliteracy; literacy in the field of copyright; skills of the century; information literacy of the XXI century; literacy in the field of augmented reality; literacy in the field of mobile information.

4 Chemerys I. M. (2008) Formuvannia profesiinoi kompetentnosti maibutnikh zhurnalistiv zasobamy inshomovnykh periodychnykh vydan [Formationof future journalistsprofessional competence by foreign language periodicals' means] ( $\mathrm{PhD}$ in Pedagogic sciences). Kyiv: Institute of Higher Education of the National Academy of Pedagogical Sciences of Ukraine, p. 45.

5 Kurbanoglu S. (2013) Media Literacy: A Report of the National Leadership Conference on Media Literacy. Aspen, CO: Aspen Institute, 1993.Analiz kontseptsii informatsionnoy gramotnosti [Analysis of information literacy concept]. Media- $i$ informatsionnaya gramotnost $v$ obshchestvakh znaniya [Media and information literacy in knowledge societies]. Moscow: Mezhregionalnyy tsentr bibliotechnogo sotrudnichestva, p. 87.

${ }^{6}$ Bukkhorst A. (20 13). Media and information literacy and its "friends". Media and information literacy in knowledge society. Moscow: Mezhregionalnyy tsentr bibliotechnogo sotrudnichestva, p. 35 . 
However, the term "information literacy" has taken root, and it is now widely recognized and widespread. For a long time it was actively used, primarily in the field of library and information, but gradually the concept went beyond it. The term was further developed in later documents approved at international forums. In particular, the Prague Declaration of 2003, entitled "Towards an Information Literate Society", linked information literacy to the information society, and the Alexandria Declaration "Information Society Lighthouses" (2005) marked the relationship between information literacy and lifelong learning.

The Information Literacy Section of the International Federation of Library Associations and Institutions (IFLA) in 2006 discussed the possibility of replacing the term "information literacy" with one that is linguistically more acceptable for other major languages. However, as a result, it was decided to keep the term, given that it has already received international recognition. However, in each country it was recommended to choose the most appropriate term for your language. Today in Ukraine it is "information literacy".

It should be noted that nowadays information literacy is more and more often mentioned in the context of a new combined term - "media and information literacy" (MIG). American professor J. Potter notes that a Google search yields 765,000 results for "media literacy"7, which underscores the growing interest in this issue, but to assess the importance of both theoretical and practical work in this area to date is not seems possible because there is a tendency of local conceptualization of approaches, which significantly complicates the understanding of media literacy as a phenomenon. R. Hobbs, an American media education specialist and director of the US Media Education Lab, compares media education to a child with a thousand names ${ }^{8}$.

Media literacy is a so-called umbrella term, as in social theory there is no single definition of this concept. The most common interpretation of media literacy is the following: media literacy is the ability to access, analyse and transmit messages of various types 1; media literacy is the attitude of questions to the content of what a person watches, reads, listens to ${ }^{9}$.

${ }^{7}$ Potter W. (2010) James The State of Media Literacy. Journal of Broadcasting \& Electronic Media, vol. 54(4). P. 675-696. https://doi.org/10.1080/08838151.2011.521462

${ }^{8}$ Hobbs R. (1994) Pedagogical issues in U.S. media education. In S. Deetz (ed.). Communication Yearbook 17. Newbury Park CA: Sage Publications, p. 453.

${ }^{9}$ Kotlyar P. S. (2017) Mediagramotnost v usloviyakh razvitiya tsifrovykh tekhnologiy [Media literacy in the development of digital technologies]. Herald of Vyatka State University: philosophical sciences, no. 8, p. 26. 
The term "media competence" is becoming more and more popular every year in scientific publications, mainly in the works of teachers, journalists, sociologists. And it is no coincidence that this concept is one of the central ones in the new concept of modern education. The growing flow of information requires from the individual not only adequate perception, effective processing of information, but also creative thinking and critical analysis of media messages. In this context, the formation of media competence of the individual becomes an integral part of modern education ${ }^{10}$.

UNESCO has held several expert meetings on various aspects of media and information literacy, including the Meeting on the Implementation of Media and Information Literacy Components in Teacher Training Curriculum (Paris, June 2008) and the Meeting on the Development of Media and Information Literacy Indicators (Paris, June 2008). Bangkok, November 2010). In 2017, UNESCO published the main provisions of the five rules it proposed on media and information literacy.

In these documents, UNESCO combines information and media literacy (LawsofMediaandInformationLiteracy, MIL), highlighting common concepts for both areas. The organization also positions these two areas as a combination of knowledge and skills needed by modern society around the world.

"It is important for citizens to understand the functions of the media and other sources of information, to critically evaluate their content, as well as to make informed decisions - both users and producers of media content and information," - explained in the organization. The MIL rules cover all types of media and other sources of information - libraries, archives, museums and the Internet, regardless of the technology used. Particular attention will be paid to training teachers to involve them in the implementation of MIL in the learning process, providing them with appropriate pedagogical methods, curricula and resources.

Principle 1. Information, communication, libraries, media, technologyand the Internet should be used critically by society. They are equal in stature and none is more relevant than the other or should be ever treated as such.

Principle 2. Every citizen is a creator of information / knowledge. Everyone has the right of access to information / knowledge and the right to self-expression. Media and information literacy must be for all - both men and women - and a nexus of human rights.

10 Zhizhina Marina (2016) Media Competence as Strategic Objective of Media Education: Criteria of Media Competence. Mediaobrazovanie-Media Education, no. 4, p. 47. 
Principle 3. Information, knowledge and communication are not always value neutral, independent or impartial. Any conceptualization, use and application of MIL should make this statement transparent and understandable to all citizens.

Principle 4. Every citizen wants to know and understand new information, knowledge and messages as well as to communicate with others, even if he does not express this desire. Their rightsmust however never be compromised.

Principle 5. Media and information literacy is not acquired at once. It is a lived and dynamic experience and process. It is complete when it includes knowledge, skills and attitudes, when it covers access, evaluation/ assessment, use, production and communication of information, media and technological content ${ }^{11}$.

There are many definitions of "media competence" today. Media competence is the quality of a person media literate. It is the result of media education, which helps a person to actively use the opportunities of the information and educational field - television, radio, video, press, Internet, forms a culture of communication, develops creative, communicative skills, critical thinking, ability to perceive, interpret, analyze and evaluate media texts, teach various forms of self-expression through educational technologies, including media technologies. It is media competence that develops the skills of professionally oriented critical thinking, which help to make independent judgments and make competent decisions in response to information transmitted through mass media ${ }^{12}$.

It should be noted that in Ukraine these concepts (IG, MG, MIG) are now used much less than in other countries whose higher education institutions have high ratings. And this is evidence that we are somewhat lagging behind in the development of those new areas of humanitarian knowledge that have been successfully developed in recent decades by the humanities of other countries. We usually use variations of the concept of "information and communication technologies", which came to the humanities in the field of informatics, but is also basic in humanities research. Our review raises awareness of the need to operate with new terms that have become usual in the scientific and educational environment. And as sooner they are activated

${ }^{11}$ Media Sapiens (24 february 2017) UNESCO has published five principles of media and information literacy. Retrieved from: https://ms.detector.media/mediaosvita/ post/18453/2017-02-24-yunesko-opublikuvala-pyat-printsipiv-mediinoi-ta-informatsiinoigramotnosti/.

12 Fedorov Alexander (2001). Media Education: History, Theory and Methods. Rostov: BBP. P. 168. 
in the educational field of higher education, the more successfully the tasks of education will be solved ${ }^{13}$.

In addition, it is impossible to achieve success in lifelong learning without media education, no matter what the education system. This is a new philosophy of pedagogical activity, which probably needs its own educational system.

One of the most cited researchers O. Fedorov gives the following interpretations of the concept of "media competence of the individual" and "media competence of the teacher"14. Educator's media competence - a set of its motives, knowledge, skills, abilities (indicators: motivational, contact, information, perceptual, interpretive / evaluative, practical-operational / activity, creative), which contribute to the selection, use, critical analysis, evaluation, creation and transmission of media texts in different types, forms and genres, analysis of complex processes of media functioning in society.

Ukrainian media educators have proposed a brief definition of the specialist's media competence concept: it is an integral characteristic of the individual, which consists of individual partial competencies and is a feature of media culture ${ }^{15}$.

Currently A. Onkovich in his monograph "Media information literacy as an umbrella term", draws the attention of the scientific and pedagogical community to the potential of vocational media education in higher education, through which the future specialist becomes media and information literate and can significantly modernize the learning process in the student auditorium. You can take advantage of the richness of the modern information environment by mastering media and information literacy in media education classes, which, in particular, attest to the work of graduate students of the Institute of Higher Education NAPS of Ukraine, approbation programs of special courses which are included in the collection "Media Didactics"16. The research of N. Dukhanina, I. Sakhnevych, I. Chemerys, O. Yanyshyn and others led us to understand that it is time to talk not just about media education, which some understand as "journalism

${ }^{13}$ Kotlyar P.S. (2017) Mediagramotnost v usloviyakh razvitiya tsifrovykh tekhnologiy [Media literacy in the development of digital technologies]. Herald of Vyatka State University: philosophical sciences, no. 8, p. 26.

14 Fedorov Alexander (2001). Media Education: History, Theory and Methods. Rostov: BBP, p. 295.

15 Onkovych Ganna, Dukhanina N. M., Sakhnevych I. A., Hurinenko I. A., Yanishin O. K., Onkovich A. D., Balabanova K. E. (2013) Mediadydaktyka vyshchoi shkoly: prohramy spetskursiv [Media didactics of higher school: special coursesprograms]. Kyev: Logos (in Ukrainian), p. 17.

${ }^{16}$ Ibid., p. 18. 
for all", but about professionally oriented media education ${ }^{17}$.Media education in higher education involves the training of not only specialists for the media, media educators and media psychologists. In order to develop media information literacy, media educational elements should be included in the curricula of professionally-oriented humanitarian training cycle in other specialties in the appropriate volumes. Subject methods of media education, used today in higher education in Ukraine, testify to the prospects and feasibility of developing various media education technologies, as their availability and diversity contribute to the formation of professional competence of future professionals ${ }^{18}$.

\section{Media literacy in the development of digital technologies}

Today we can say that there has been an expansion of the set of physiological human needs. Thus, in line with the basic biological needs for rest, food, reproduction is the need of another nature - the need for information. The benefit of information is directly related to human needs through information a person ensures their safety, recreation, well-being. However, those who have the ability to pay for traffic, the relevant competencies for the use of digital devices, as well as knowledge of reliable information sources and access to them, understanding the possibility of practical application of information can be involved in the information and communication system. The impossibility of fulfilling these conditions determines the emergence of an information gap between groups of the population, which allows us to speak of the emergence of a new class division: the information elite and the information plebs.

The process of formation of information and practical orientation of users acts as the most actual problem which needs theoretical comprehension. In other words, the latest digital technologies with detailed instructions for their development are not full-fledged digital tools without addressing the issue of cultural-reflexive attitude of the user to the media. There is a number of problems associated with finding information, such as the low threshold of the expected result, when the user stops searching and is satisfied with the information he encounters. For example, researcher D. Cheney notes that students "usually use the information they come across rather than decide what information they need"; use of a limited set of search

${ }^{17}$ Onkovych Ganna, Dukhanina N. M., Sakhnevych I. A., Hurinenko I. A., Yanishin O. K., Onkovich A. D., Balabanova K. E. (2013) Mediadydaktyka vyshchoi shkoly: prohramy spetskursiv [Media didactics of higher school: special coursesprograms]. Kyev: Logos (in Ukrainian), p. 25.

18 Onkovich G. V. (2020) High school mediadidactics development: Ukrainian experience. Printing Horizon, vol. 1 no. 8, p. 130. 
strategies; lack of verification of the received information and its uncritical perception. In today's density of information flows, people minimize the presence of negative content. This is reflected in the tendency to refrain from viewing news reports that report terrorist acts, natural disasters and other emergencies in favor of news about events in show business, sports, entertainment ${ }^{19}$.

Elements that contribute to the dissemination of information, at the same time act as factors that determine the relationship between man and the media sphere, in which the procedures for the exchange, translation and reproduction of information.

One of the main elements of the media is the interface. According to media theorist M. Kurtov, "interface" is a combination of "external hardware", such as display, keyboard, mouse and programming language ${ }^{20}$. A key feature of the interface is its "transparency". Users do not perceive the interface directly, it is beyond their attention and manifests itself in moments of failure, when the user sees a graphical confirmation of the problem. The interface, taken in extreme form, is the surrounding human world. B. Gates and E. Schmidt predicted the dissolution of the Web in the world ${ }^{21}$.

Digital code is the language of storing and transmitting information to new media. Digital gadgets provide access to the information environment at any time. This is what caused the radical changes in the classical structure of information transmission using analog media. The digitization of traditional media actually marked a digital revolution, when a special digital environment emerged that changed the social characteristics, especially of spiritual production. Note the most important aspects of the transformation that has taken place as a result.

Hypertextuality is the subsequent interaction of the user and the digital environment. Hypertextuality (or "nonlinearity") is the main difference between digital and printed text.

Another unifying element of the digital sociosphere is interactivity. Interactivity as a phenomenon is an interaction between the participants of any modern dialogue or polylogue, in addition to changing the role of

${ }^{19}$ Vahlberg V., Peer L., Nesbit M. (2008) If It Catches My Eye: An Exploration of Online News Experiences of Teenagers. Evanston. IL: Media Management Center, Northwestern University, $56 \mathrm{p}$. Retrieved from: URL: https://www.americanpressinstitute.org/ wp-content/uploads/2013/09/NIE_If-it-catches-my-eye-2008.pdf.

20 Kurtov Michael (2014) Genezis graficheskogo polzovatelskogo interfeysa. K teologii koda. Sankt-Peterburg: TransLit, p. 34.

21 Kotlyar P.S. (2017) Mediagramotnost v usloviyakh razvitiya tsifrovykh tekhnologiy [Media literacy in the development of digital technologies]. Herald of Vyatka State University: philosophical sciences, no. 8, p. 26. 
viewer-listener-user from passively perceiving, abstract to a key figure of the media space. For example, as a criterion for assessing the potential of a blogger's participation in an advertising campaign, the advertiser evaluates his audience, namely the number of likes and comments under his posts. The growth of interactivity transforms cultural logic. At the same time, interactivity creates an ambiguous phenomenon of new media of the old type, when a certain media source is on a digital platform, but denies its recipients the opportunity to participate equally in the production of content. This leads to the emergence of new information channels in which former recipients become producers of their own product. Such a change in user status is a compensation for monopolistic information discourse in favor of free interpretation of information.

High culture in its classical sense is being transformed into a new digital culture, and now mass culture is also becoming the object of digital determination, making it virtually impossible to differentiate the product consumed by the new recipient ${ }^{22}$. For example, attending a concert of a popular artist is a manifestation of interest in his work or a desire caused by the memofication of his content or personality? The ability to decode memes (media object) serves as a condition for successful network communication. Memofication is the main trend of the modern media environment. A meme is a unit of the information environment that can be replicated multiple times. M.Kronhaus defines a meme as follows: “... language clichés related to one specific situation or text (film, novel, etc.). Becoming fashionable, they are reproduced in many other situations, appropriate or inappropriate. Memes, having a real source, as they spread, become overgrown with new details, the authenticity of which is extremely difficult to verify. Sources are erased, disappear, important fragments are removed, and the legend becomes more important than reality" ${ }^{23}$.

One of the components of the new media environment is mobility. The development of the Internet and gadgets has changed the identity of users and has become a major factor in cultural globalization. In this context, media devices and media content constitute an organic unity, an object of fetishization, which from a means becomes a way of existence.

Earlier we showed that the orientation of users within the information flows of new media includes an understanding of the principles of human

22 Kotlyar P.S. (2017) Mediagramotnost v usloviyakh razvitiya tsifrovykh tekhnologiy [Media literacy in the development of digital technologies]. Herald of Vyatka State University: philosophical sciences, no. 8, p. 26.

${ }^{23}$ Krongauz M. A. (2013) Samouchitel olbanskogo [Albanian self-teacher]. Moscow: AST: CORPUS, p. 18. 
interaction and digital technology. We proposed to consider this relationship from the standpoint of not an instrumental understanding of the media, but spatial. Thus, media literacy is a condition for the successful expansion of the media environment, which differs from the understanding of media literacy as a technical skill in a situation where a person uses digital technology only as a new form, losing the opportunity to constructively oppose media reality and accept their new subjectivity.

Analysis of research, project materials and documents on the competency approach shows that media literacy is not invariant in the current domestic and foreign concepts, but it is inevitably present in the descriptions of the components of various competencies. Thus, in the materials of the symposium "Key Competences for Europe" (Bern, 1996) skills and abilities to interact with media texts are attributed to the competencies associated with the growth of informatization of society, which provide readiness and need to competently and critically use modern sources of information in professional and domestic areas of activity ${ }^{24}$. According to the classification of key competencies of I. A.Zymova, the goals and objectives of media literacy can be realized in the development of competencies of value and semantic orientation in the world and society, the competence of social interaction with society and communities, the competence of cognitive activity $^{25}$.

However, given the modern paradigm of information civilization and the role played by the media in creating an information environment, scientists consider it appropriate to consider media literacy as a separate, independent competence in the structure of professional competence of modern professionals and mark it as a key competence in the system "key - basic special"competencies.

Highlighting media literacy as a key competence in the structure of professional competence of a modern specialist requires the definition of its structural components and content. Like any other competency, media literacy is a set of skills, abilities, value systems and attitudes. Attempts to structure the content of media literacy are presented in the works of most domestic and foreign theorists of media education. The most common version of the system of key concepts proposed by the British Film Institute

${ }^{24}$ Hutmacher W. Key (1997) Competences for Europe: Report of the Symposium (Berne, Switzerland, March 27-30, 1996). A Secondary Education for Europe Project. Council for Cultural Cooperation, Strasbourg, p. 56.

25 Zimnyaya I. A. (2003) Klyuchevye kompetentsii - novaya paradigma rezultata obrazovaniya [Key competencies are a new paradigm of educational outcome]. Higher Education Today, no. 5, p. 34. 
includes such categories as media agencies, media categories, media technology, media language, media auditors, media representation ${ }^{26}$.

Approaches to the formation of media literacy, based on key concepts, have both obvious advantages (for example, allow the use of a unified set of categories when working with different types of media texts), and some disadvantages. In particular, according to E. Hart, claiming absolute neutrality in relation to the value systems preached by the media, these approaches risk creating a spiritual vacuum in the learning process ${ }^{27}$.

Some researchers of media literacy suggest building its content around exclusively value, ideological or aesthetic components and focus the learning process, for example, on the study of ideological production in the media or the aesthetic component of media messages ${ }^{28}$.

There are other approaches to describing the structure of media literacy in the scientific literature. For example, R. Hobbes, based on a common definition of media literacy, developed by an international group of experts, proposes to distinguish four groups of skills in its structure: the ability to access, the ability to analyze, the ability to evaluate and the ability to create media texts ${ }^{29}$. All these skills, in our opinion, are indeed an integral component of media literacy, but in this case there is an unjustified narrowing of the structure of media literacy to the behavioral component. As in the above approaches, such a narrowing is illegal from the standpoint of considering media literacy as a key competence, determines the willingness of citizens to adequately interact with modern media culture.

Based on the provisions formulated in psychology on the characteristics of key competencies, which can be considered as general criteria for determining and evaluating their structure and content. Chicherina identifies four structural and substantive components of media literacy: motivational, cognitive, behavioral and value- semantic components ${ }^{30}$.

${ }^{26}$ Hart A. (1997) Textual Pleasures and Moral Dilemmas: Teaching Media Literacy in England. Media Literacy in the Information Age: Current Perspectives. New Brunswick, p.199.

${ }^{27}$ Zimnyaya I.A. (2003) Klyuchevye kompetentsii - novaya paradigma rezultata obrazovaniya [Key competencies are a new paradigm of educational outcome]. Higher Education Today, no. 5, p. 39.

${ }^{28}$ Zettl H. (1998) Contextual Media Aesthetics as the Basis for Media Literacy. First published in the Journal of Communication Winter, vol. 48, no. 1, p. 81.

${ }^{29}$ Hobbs R. (1997) Expanding the Concept of Literacy. Media Literacy in the Information Age: Current Perspectives. NewBrunswick; London, p. 163.

${ }^{30}$ Chicherina N. V. (2012) Media Literacy as a key competence of modern specialists: components and content. Vestnik of Northern (Arctic) Federal University.Humanitarian and Social Sciences, no. 1, p. 152. 
1. Motivational component - readiness to demonstrate competence. The motivational component is formed, first, on the basis of personal awareness of the role and functions of modern media in society and each individual in the context of changes in social reality; secondly, on the basis of forming holistic ideas about oneself in the context of modern media culture; thirdly, on the basis of comprehension of own communicative needs and actualization of intellectual possibilities in the course of active mastering of the saved up human experience at interaction with media texts.

2. Cognitive component - knowledge of the content of competence, which includes knowledge grouped by key concepts of media literacy, that include the following concepts: process, context, media text and media representation.

3. Behavioral component - a set of skills that provide adequate interaction with media texts in a variety of standard and non-standard situations. The behavioral component of media literacy includes the following basic skill groups:

- ability to search and store information in various media sources;

- ability to analyze media text: determine the topic, subject, type, genre, target audience of media text; to establish the communicative intention of the author and the meaningful dominance of the media text; identify the main functions of media text; highlight the main thing, analyze the explicit and implicit content; determine the structural organization of the narrative; analyze verbal, audital, visual, graphic, multimedia ways of conveying meaning and content; identify and analyze socio-cultural concepts that are relevant in the media text; identify intertextual connections; determine the presence or absence of stereotypical representations; determine the means of influencing the audience; explore the social, historical, political, economic and cultural contexts of media text creation and perception;

- ability to critically evaluate the content of the media text: to interpret the content of the media text through the prism of personal experience, based on already formed values, attitudes, worldview, acquired knowledge; based on the analysis of social and cultural contexts to make assumptions about possible consequences, further events or logical conclusion of the represented situation;

- the ability of creative reproductive and productive recoding of information when creating a new media text: correctly identify and evaluate the audience or recipient of media messages; effectively and creatively use verbal, auditory, visual, graphic, multimedia means and methods of conveying meaning and content; to build a logical chain, to attract and hold 
the attention of message recipients; to build communication taking into account features of a picture of the world of the partner on communication.

4. Value-content component - the attitude to the content of competence and the object of its application, formed on the basis of basic conceptual provisions of media literacy, is a kind of code that defines the "ideological basis" of the process of forming critical autonomy of media consumers: media texts are constructs, but, in turn, they construct reality; media texts have commercial, ideological and political implications; form and content are interdependent in all media, each of which has a specific set of characteristics; recipients of media texts construct their meaning and content.

In 2011, the Dutch organization that specializes in media literacy, Mediawijzer.net, turned to experts to determine the question "What is media literacy and how it can be measured". A project team led by the EYE Film Institute has pioneered work to make media literacy measurable and provided a launch document, Measuring Media Literacy. Based on their answers, a model was created to which changes will be made every year both minor and thorough. The end result is one comprehensive model that includes ten media literacy competencies. The competency model was published on November 15, 2012.

The Dutch model identifies four main components of media competence: understanding, use, communication, and strategy.

Understanding includes three competencies: understanding the current impact of the media on society; understanding of media construction; understanding how the media paint reality.

Use includes two competencies: use of hardware, software and applications; orientation in the media environment.

Communication includes three competencies: search and information processing; content creation; use of social networks.

Strategy: thinking about your own use of the media.

Understanding, Use and Communication are ultimately only conditions for the latter group of competencies: Strategies. As the meaning of the word implies, for the most part, the "media" is always a means to achieve personal, social, professional or social goals. In today's media society, it is almost impossible to achieve personal, social, professional or social goals without the use of media in any way.

From the point of Dutch experts' view, to be media literate means to realize one's own goal, based on the assessment of the possibilities (and limitations) of the media, the effective use of the media for one's own purposes. The unique way you do this ultimately determines your digital identity. 


\section{CONCLUSIONS}

It seems obvious that media literacy is a necessary condition not only to meet the information and communication needs of modern man, but also mandatory for the formation of information culture.

The above components of media literacy determine not only the structure of the formed competence, but also the content of the learning process aimed at the development of media literacy as a key competenceof the individual, that ensures adequate interaction of society with modern media culture.

The formation of media competence goes far beyond the ability to use media as a technical means: knowledge about the use of media is replaced by knowledge of how to navigate in the media space, and this requires the ability to analyze problems arising from rapidly changing and extremely flexible media technologies.

In this case, media competence is seen as an element and as the end result of media education. It becomes part of the professional subculture of professionals, a condition for the socialization of the individual in modern media, a factor in human success in a changing society. At the same time, media competence acts as a means of cognition of the multicultural world; an effective means of acquiring new knowledge; way of self-presentation and realization of potential opportunities of the person.Our analysis of the literature showed that currently research interest in the problems of media competence is only growingboth in Ukraine and around the world, experts in related fields of scientific knowledge are connected to the study of this issue, programs in the field of media education are developed and implemented, media educational courses are introduced, the number of dissertations increases, develops grant support for research in the field of formation and development of media competence. All the work done and the future, written in various documents, testifies to the practical significance of the problem and the role played by media competence in the modern media world.

\section{SUMMARY}

The article is devoted to the problems of formation and assessment of media literacy and media competence of the individual, which are important today for almost all areas and levels of educationmodernization. The presented components of media literacy determine not only the structure of the formed competence, but also the content of the learning process aimed at the development of media literacy as a key competence. This ensures adequate interaction of members of society with modern media culture.

Media competence is seen as an element and as the end result of media education. It becomes part of the professional subculture of professionals, a condition for the socialization of the individual in the modern media, a factor in human success in a changing society. The structure of media literacy as 
the main competence of the modern personality is considered. It is substantiated that the level of media literacy is the main factor in the formation of modern personality. Today, media education disciplines play an important role not only in the training of future professionals in the field of media, but also in the process of carrying out any professional activity.

\section{REFERENCES}

1. Aufderheide P. (ed.) (1993) Media Literacy: A Report of the National Leadership Conference on Media Literacy. Aspen, CO: Aspen Institute.

2. Bukkhorst A. (20 13).Media and information literacy and its "friends". Media and information literacy in knowledge society.Moscow: Mezhregionalnyy tsentr bibliotechnogo sotrudnichestva, pp. 35-44.

3. Chemerys I.M. (2008) Formuvannia profesiinoi kompetentnosti maibutnikh zhurnalistiv zasobamy inshomovnykh periodychnykh vydan [Formationof future journalistsprofessional competence by foreign language periodicals' means] (PhD in Pedagogic sciences). Kyiv: Institute of Higher Education of the National Academy of Pedagogical Sciences of Ukraine.

4. Cheney D. (2010) Fuzzy logic: Why students need news and information literacy skills. Youth Media Reporter. Retrieved from: URL:http://www.youthmediareporter.org/2010/06/24/fuzzy-logic-whystudents-need-news-and-information-literacy-skills/ (accessed 07.05.2020).

5. Chicherina Natalia Vasilyevna (2012) Media Literacy as a key competence of modern specialists: components and content. Vestnik of Northern (Arctic) Federal University. Humanitarian and Social Sciences, no. 1, pp. 152-158. CVVR [in Russian]

6. Dukhanina N. M. (2007) Pedahohichni umovy zastosuvannia mediaosvitnikh tekhnolohii u pidhotovtsi mahistriv komp'iuternykh nauk [Pedagogical conditions of application of media education technologies in preparation of masters of computer] ( $\mathrm{PhD}$ in Pedagogic sciences). Kyiv: Institute of Higher Education of the National Academy of Pedagogical Sciences of Ukraine.

7. Fedorov Alexander (2001). Media Education: History, Theory and Methods. Rostov:

8. Hart A. (1997) Textual Pleasures and Moral Dilemmas: Teaching Media Literacy in England. Media Literacy in the Information Age: Current Perspectives. New Brunswick, pp. 199-211.

9. Hobbs R. (1994) Pedagogical issues in U.S. media education. In S. Deetz (ed.). Communication Yearbook 17. Newbury Park CA: Sage Publications, pp. 453-466.

10. Hobbs R. (1997) Expanding the Concept of Literacy. Media Literacy in the Information Age: Current Perspectives. NewBrunswick; London, pp. 163-184. 
11. Hobbs R. (2001) The great debates circa 2001: The promise and potential of media literacy. Community Media Review, vol. 24(1). pp. 25-27.

12. Hutmacher W. Key (1997) Competences for Europe: Report of the Symposium (Berne, Switzerland, March 27-30, 1996). A Secondary Education for Europe Project. Council for Cultural Cooperation, Strasbourg (France).

13. Kotlyar P.S. (2017) Mediagramotnost v usloviyakh razvitiya tsifrovykh tekhnologiy [Media literacy in the development of digital technologies]. Herald of Vyatka State University: philosophical sciences, no.8, pp. 26-32.

14. Krongauz M. A. (2013) Samouchitel olbanskogo [Albanian selfteacher]. Moscow: AST: CORPUS [in Russian]

15. Kurbanoglu S. (2013) Media Literacy: A Report of the National Leadership Conference on Media Literacy. Aspen, CO : Aspen Institute, 1993.Analiz kontseptsii informatsionnoy gramotnosti [Analysis of information literacy concept]. Media- $i$ informatsionnaya gramotnost $v$ obshchestvakh znaniya [Media and information literacy in knowledge societies]. Moscow: Mezhregionalnyy tsentr bibliotechnogo sotrudnichestva, pp. 87-97.

16. Kurtov Michael (2014) Genezis graficheskogo polzovatelskogo interfeysa. K teologii koda []. Sankt-Peterburg: TransLit. [in Russian]

17. Lewis J., Jhally S. (1998) The Struggle over Media Literacy. First published in the Journal of Communication Winter, vol. 48, no. 1, pp. 109-120.

18. Media literacy Competency model. Media literacy: definition in 10 competences. Retrieved from: https://www.mediawijzer.net/vanmediawijzer-net/competentiemodel (accessed 10 May 2020).

19. MediaSapiens (24 february 2017) UNESCO has published five principles of media and information literacy. Retrieved from: https://ms.detector.media/mediaosvita/post/18453/2017-02-24-yuneskoopublikuvala-pyat-printsipiv-mediinoi-ta-informatsiinoi-gramotnosti/ (accessed 10 May 2020).

20. Onkovich G. V. (2020) High school mediadidactics development: Ukrainian experience. Printing Horizon, vol. 1 no. 8, pp. 130-150. https://doi.org/10.20535/2522-078.2020.1(8).190094

21. Onkovych Ganna (2013) Mediakompetentnist - fakhova yakist suchasnoho spetsialista [Media competence - the professional quality of a modern specialist]. Mediakompetentnist fakhivtsia: kolektyvna monohrafiia [Media competence of a specialist: a collective monograph]. Kyev: Logos, pp. 6-15.

22. Onkovych Ganna, Dukhanina N.M., Sakhnevych I.A., Hurinenko I.A., Yanishin O.K., Onkovich A.D., Balabanova K.E. (2013) Mediadydaktyka vyshchoi shkoly: prohramy spetskursiv [Media didactics of higher school: special coursesprograms]. Kyev: Logos (in Ukrainian) 
23. Pocheptsov Georgiy. Koronavirus vskryvaet konflikty: media i feyki, politika i vragi [Coronavirus reveals conflicts: media and fakes, politics and enemies].Retrieved from: https://www.stopfake.org/ru/koronavirusvskryvaet-konflikty-media-i-fejki-politika-i-vragi/ (accessed 15 May 2020).

24. Potter W. (2010) James The State of Media Literacy. Journal of Broadcasting \& Electronic Media, vol. 54(4). pp. 675-696. https://doi.org/10.1080/08838151.2011.521462

25. Sakhnevych I.A. (2012) Pedahohichni umovy vykorystannia mediaosvitnikh tekhnolohii u profesiinii pidhotovtsi maibutnikh fakhivtsiv naftohazovoho profiliu [Pedagogical conditions for the use of media educational technologies in the training of future oil and gas specialists] (PhD in Pedagogic sciences). Kyiv: Institute of Higher Education of the National Academy of Pedagogical Sciences of Ukraine.

26. Vahlberg V., Peer L., Nesbit M. (2008) If It Catches My Eye: An Exploration of Online News Experiences of Teenagers. Evanston. IL: Media Management Center, Northwestern University, 56 p. Retrieved from: URL: https://www.americanpressinstitute.org/wp-content/uploads/2013/09/NIE_ If-it-catches-my-eye-2008.pdf. (accessed 01.05.2018)

27. Yanyshyn O.K. (2012) Formuvannia komunikatyvnykh umin maibutnikh dokumentoznavtsiv zasobamy mediaosvitnikh tekhnolohii [Formation of communicative skills of future documentologists by media educational technologies' means](PhD in Pedagogic sciences). Kyiv: Institute of Higher Education of the National Academy of Pedagogical Sciences of Ukraine.

28. Zettl H. (1998) Contextual Media Aesthetics as the Basis for Media Literacy. First published in the Journal of Communication Winter, vol. 48, no. 1, pp. 81-95.

29. Zhizhina Marina (2016) Media Competence as Strategic Objective of Media Education: Criteria of Media Competence. Mediaobrazovanie-Media Education, no.4. pp. 47-65.

30.Zimnyaya I.A. (2003) Klyuchevye kompetentsii - novaya paradigma rezultata obrazovaniya [Key competencies are a new paradigm of educational outcome]. Higher Education Today, no. 5, pp. 34-42. [in Russian]

\section{Information about the author:} Kostyrko T. N., $\mathrm{PhD}$ in Social Communication, Director of the Scientific Library, Admiral Makarov National University of Shipbuilding, 9, Heroes of Ukraine Avenue, Mykolaiv, 54025, Ukraine ORCID ID: orcid.org/0000-0002-4175-9975 